\title{
복지국가와 공적개발원조
}

\section{목차}

I. 서론

II. 한국 공적개발원조의 특성

III. 국제협력을 위한 국내적 토대의 중요성: 일본과 스웨덴 사례

IV. 공적개발원조의 방향: 인권으로서의 개발

$\mathrm{V}$. 결론

\section{I. 서 론}

국내적으로 '복지'에 대한 관심이 뜨겁다. 비정규직과 근로빈곤층이 증가하고 이로 인한 사회적 불 안이 커지면서, 사회적 안전망 확대에 대한 요구가 증가하고 있는 것이다. 그럼에도 불구하고 한국 사회의 '반(反)복지의 덫'은 여전히 강고해 보인다. 무엇보다 한국 사회에 팽배한 퇴행적 복지 의식이 '국가' 복지의 제도적 발전에 큰 걸림돌이 되고 있다. 우리는 선한 국가 혹은 공적 시혜 체제에 대한 경험, 즉 국가나 사회로부터 무엇을 받아 본 변변한 기억이나 경험을 가져보지 못했다. 그래서 시장 과 경쟁에서 밀려난 사람들은 자신의 불행을 공동의 사회문제로 승화시키기보다는 자책하고 체념하 는 데 익숙하다. ${ }^{1)}$

반면, 북유럽 복지국가를 대표하는 스웨덴 사민당의 사회정책은 "안전이란 개인이 자신의 힘만으 로 풀려고 하기에는 너무도 큰 문제이며, 근대사회의 문제들은 점점 더 협동 · 협력 · 연대에 바탕을 둔 조치들을 요구한다"는 인식에서 생겨났다. 이러한 인식에 기초해 사민당은 개인들이 시장에서 차 지하고 있는 지위가 그들의 삶의 기회를 전적으로 결정하지 못하도록 하기 위해 국가 개입을 통해 불

1) 한국 사회의 '반복지의 덫'에 관해서는 고세훈, 『복지한국, 미래는 있는가』, (서울: 후마니타스, 2009), 2장을 참조. 
확실성과 불안정으로부터 국민들을 보호하고자 했다. ${ }^{2)}$

흥미로운 점은 국내적 수준에서 연대성, 포용성, 보편적 복지의 가치를 증진시키고자 하는 국가들 이 국가적 경계를 넘어 전지구적 수준에서도 이러한 가치를 증진시키고자 할 가능성이 크다는 사실이 다. 2010년 OECD 예비 자료3) 기준으로 국민총소득(GNI: Gross National Income) 대비 공적개발원 조(Offical Development Assistant, 이하 ODA) 비율을 살펴보면, 복지국가성과 해외원조가 일정한 관련성을 지님을 살펴볼 수 있다. 에스핑-안데르센(Esping-Andersen)의 복지국가 분류)에서 사회 민주주의 체제로 분류되는 덴마크(0.9\%), 스웨덴(0.97\%), 노르웨이(1.10\%)와 같은 북유럽 국가들이 가장 높은 비율을 차지했다. 반면, 자유주의 체제로 분류되는 오스트레일리아(0.32\%), 캐나다 (0.33\%), 일본(0.20\%), 영국(0.56\%), 미국(0.21\%)은 OECD 개발원조위원회(Development Assistance Committee, 이하 DAC)의 가이드라인인 GNI 대비 ODA 비율 $0.7 \%$ 에 미치지 못했다. 한국은 $\mathrm{OECD}$ 전체 국가 중 가장 낮은 $0.12 \%$ 에 불과하다.

북유럽 국가들의 해외원조 비율이 높은 이유는 이들 국가들의 복지국가 모델과 국제주의적 전통이 관련성을 갖기 때문이다. 스웨덴은 특히 이러한 모습을 보여주는데, 사민당의 당의장이었으며 총리 를 역임했던 올로프 팔메(Olof Palme)는 일찍이 “연대에는 국경이 없다”고 주장하면서 분배적 정의 에 대한 국내적 호소가 국제적 호소와 상호 구성적인 관계를 갖는다고 주장했다. ${ }^{5)}$ 스웨덴의 사회 민 주주의적 복지국가는 담론과 실천에서 연대성을 사회적으로 구성할 수 있는 유효한 토대를 만들어 왔고, 이는 국내 정치에 한정되지 않고 국제적 차원에서 연대성을 추구해 나가는 것으로 확장될 수 있었다. 역사적으로 볼 때 스웨덴의 복지국가가 다른 대부분의 복지국가들보다 보편주의적이었으며, 사회경제적 평등을 실현하는 데 훨씬 더 뛰어났기 때문이기도 하다. 중요한 사실은 사회적 연대성에 대한 누적된 규범이 보다 일반적으로 스웨덴을 비롯한 북유럽 국가들의 국제주의를 유지시키는 역할 을 했다는 점이다.

이것은 국내적 복지의 보편적 제공과 지구적 차원의 불평등을 줄이기 위한 해외원조가 일정한 친 화성을 가질 수 있음을 뜻한다. ${ }^{6)}$ 다시 말해, 국내적으로 복지에 대한 시민사회의 퇴행적 의식과 담 론을 극복하고 복지국가에 대한 규범을 형성하는 과정이 곧 해외원조의 의무에 대한 사회적 합의를 높이는 길이 될 수 있다는 것이다. 역으로 양적 성장만을 중시하는 반복지 담론은 해외원조에 대한 일반 국민들의 부정적 태도를 초래할 수 있으며 원조를 하더라도 배타적인 국익의 관점만을 강조할 가능성이 크다.

2) 버먼, 셰리 저, 김유진 역, 『정치가 우선한다』, (서울: 후마니타스, 2010), p. 291.

3) OECD, "ODA in 2010(preliminary)," Reference DAC Statistical Tables, 2011년 4월.

4) Esping-Andersen, Gøsta, The Three Worlds of Welfare Capitalism, (Princeton: Princeton U. P., 1990).

5) Bergman, Annika, "Co-Constitution of Domestic and International Welfare Obligations," Cooperation and Conflict 42, No. 1 (2007), pp. 74.

6) 복지국가와 해외원조의 상관관계에 대한 엄밀한 경험적 분석은 이 글의 범위를 뛰어넘는다. 하지만 적어도 국내적 복지 제도의 차이가 해외원조 정책에 영향을 준다는 점은 광범위하게 받아들여지고 있다. Noël, Alain and Jean-Philippe Thérien, "From domestic to international justice: the welfare state and foreign aid," International Organization 49, No. 3 (1995), pp. 523-553을 참조. 
우리는 더 이상 국내적인 것과 국외적인 것의 경계가 명확히 구분되는 시대에 살고 있지 않으며, 광 범위한 전지구적 상호의존 속에서 살아가고 있다. 기상 이변, 금융 위기, 테러리즘 등 세계의 다른 곳 에서 일어나는 일이 우리의 삶에 직접적으로 영향을 주고 있다. 이런 점에서 국제사회를 경쟁의 논리 가 지배적인 냉혹한 약육강식의 세계로 바라보고 배타적 국익만을 추구하는 것은 시대착오적이다. 더 구나 지구화가 지구적 빈곤을 심화하면서 부유한 나라들의 책임이 어느 때보다 강조되고 있다. 2000 년 유엔의 천년개발목표(Millennium Development Goals) 채택을 계기로 개발도상국의 빈곤 퇴치와 지속 가능한 개발을 위한 국제 사회의 공동 노력이 가속화되고 있다. 이러한 노력은 특히 개도국에 대 한 $\mathrm{ODA}$ 를 늘리고, 원조의 효과성을 키우는 데 초점이 맞춰지고 있다. 이에 비춰본다면, 한국의 공적 개발원조는 양적 측면이나 내용적 측면에서 모두 지나치게 편협한 모습을 보인다. 주의해야 할 점은 국제개발협력을 위한 양적 규모의 증가가 외부적 규범에 대한 수동적 반응에 그쳐서는 안 된다는 점이 다. 내부적인 사회적 합의가 뒷받침되지 않는다면, 국내 여론이 바뀌게 되면 언제든 퇴행할 가능성을 갖기 때문이다. 본문에서 일본 사례를 통해 이러한 점을 보여줄 것이다. 이 글에서는 국제개발협력에 대한 국제적 규범과 복지에 대한 국내적 규범이 상호 연관성을 가져야 한다는 점을 주장하려고 한다. 이런 점에서 국내적으로 국가 복지의 낙후된 제도화 수준을 변화시킬 수 있는 규범과 정치적 실천을 늘려가는 것이 중요하다. 이러한 규범과 실천이 해외원조를 이해하고 실행하는 틀이 될 수 있기 때문 이다. 인간의 기본적인 '권리’로서 복지가 이해될 수 있다면, 이를 모든 사람에게 보장하기 위한 세계 시민적 '의무’는 보다 받아들여지기 쉽다. 또한 복지국가를 위한 국내적인 규범과 실천은 해외원조가 경제 상황이나 국내적 여론에 따라 퇴행할 수 있는 가능성을 줄여줄 수 있을 것이다.

\section{II. 한국 공적개발원조의 특성}

정부 수립 이후 1990 년대 초까지 원조를 '받는 나라'7) 였던 한국은 1992 년 기술협력분야에서 UNDP가 분류하는 원조 공여국(供與國)이 되었고, 1996년에는 세계은행의 개발차관 공여 대상국에서 제외되었 다. 1987 년 대외경제협력기금(EDCF), 1991 년 한국국제협력단(KOICA)의 설립을 통해 ODA 공여사업을 본격적으로 진행해 왔으며, 2009년 11월 $\mathrm{OECD/DAC}$ 에 가입하였다. 이는 일본에 이어 아시아에서는 두 번째이고, 전 세계적으로는 스물네 번째이며, 특히 원조를 받던 나라가 OECD/DAC의 회원국으로 바뀐 첫 번째 사례로 평가받고 있다. 세계 최초로 수원국에서 공여국으로 전환하면서 DAC 회원국이 된 한국 은 $\mathrm{ODA}$ 의 국제적 흐름과 개도국의 요구에 한층 더 적극적으로 부응해야하는 책임을 안게 되었다. ${ }^{8)}$

7) 1945년부터 1999년까지 한국에 지원된 전체 ODA 규모는 128억 달러로 추산되는데, 이와 같은 대규모 원조가 한국의 근대화 및 경제성장의 중요한 토대를 제공했음은 물론이다. 구정우 - 김대욱, "세계사회와 공적개발원조: 한국 ODA 결 정요인 분석, 1989-2007," 『한국사회학』제45집 1호 (2011), p. 155 참조.

8) 고경민 · 김순임 · 홍진혁, "공적개발원조(ODA)와 국익: 한국 ODA 정책의 발전을 위한 함의," 『한국과 국제정치』제26 권 3호 (2010), p. 96. 


\section{〈그림 1〉한국의 ODA 규모 변화 추이 (순지출 기준)}

(단위: 백만 달러)

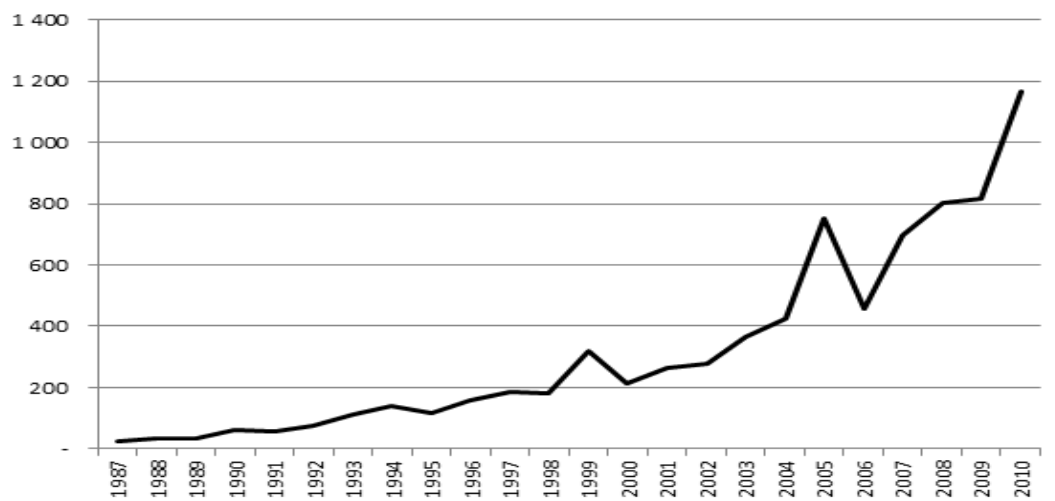

* 출처: OECD, "Development Database on Aid from DAC Online."

한국의 ODA 공여 규모는 〈그림 1〉에서 볼 수 있는 것처럼 1987 년 이후 비교적 꾸준히 증가해왔 다. 한국의 ODA 정책은 대체로 정권이 표방하는 국정목표의 영향을 받았다. 원조 공여 초창기인 1998년 92년까지는 외교수단으로 ODA를 활용하는 국익 우선의 원조정책이 강조되었다. 이후 문민 정부(1993 97년) 시기에는 세계화라는 국정목표 달성을 위한 수단으로 ODA가 활용되었으며, 국민 의 정부(1998 2002년) 시기에는 보편윤리와 인도주의적 원조가 이전 시기에 비해 강조되었다. 참여 정부 시기인 2005년에는 향후 10 년간의 ODA 정책 추진 방향을 담은 “대외원조개선 종합대책”이 수 립되었으며, 2009년에는 DAC 가입을 계기로 국제개발협력기본법이 제정되었다. $\left.{ }^{9}\right)$

\section{〈표 1〉한국의 ODA 공여현황 (순지출 기준)}

(단위: 백만 달러)

\begin{tabular}{|c|c|c|c|c|c|c|c|c|c|c|c|}
\hline \multicolumn{2}{|c|}{ 연도 } & 2000 & 2001 & 2002 & 2003 & 2004 & 2005 & 2006 & 2007 & 2008 & 2009 \\
\hline \multicolumn{2}{|c|}{ ODA 합계 } & 212.07 & 264.65 & 278.78 & 365.91 & 423.32 & 752.32 & 455.25 & 696.11 & 802.34 & 815.80 \\
\hline \multirow{3}{*}{$\begin{array}{c}\text { 양자간 } \\
\text { 원조 }\end{array}$} & 합계 & 131.18 & 171.54 & 206.76 & 245.17 & 330.76 & 463.30 & 376.06 & 490.52 & 539.22 & 580.27 \\
\hline & 무상원조 & 47.78 & 52.97 & 66.70 & 145.46 & 212.09 & 318.00 & 258.95 & 358.33 & 368.67 & 366,14 \\
\hline & 유상원조 & 83.41 & 118.57 & 140.06 & 99.71 & 118.68 & 145.30 & 117.11 & 132.19 & 170.55 & 214.13 \\
\hline \multicolumn{2}{|c|}{ 다자간 원조 } & 80.89 & 93.11 & 72.02 & 120.74 & 92.56 & 289.01 & 79.19 & 205.59 & 263.12 & 235.53 \\
\hline \multicolumn{2}{|c|}{ 무상원조 비율(\%) } & 36.4 & 30.9 & 32.3 & 59.3 & 64.1 & 68.6 & 68.9 & 73.1 & 68.4 & 63.1 \\
\hline \multicolumn{2}{|c|}{ ODA/GNI(\%) } & 0.04 & 0.06 & 0.05 & 0.06 & 0.06 & 0.10 & 0.05 & 0.07 & 0.08 & 0.10 \\
\hline
\end{tabular}

* 출처: OECD, "Development Database on Aid from DAC Online."

9) 구정우 · 김대욱, “세계사회와 공적개발원조: 한국 ODA 결정요인 분석, 1989-2007," p. 155. 
$\mathrm{OECD} \mathrm{DAC}$ 가 권고하고 있는 ODA 가이드라인은 GNI 대비 ODA 비율 0.7\% 유지, 무상원조, 비구속 성 원조, 최빈국 우선 지원, 참여 · 민주화 - 굿 거버넌스 · 인권 향상, ODA 효율성 제고를 원칙으로 하고 있다. 이 가이드라인과 비교해 보면, 한국의 대외원조가 갖는 협애성이 잘 드러난다. 첫째, 한국 의 ODA 규모는 GNI 대비 ODA 비율이 가이드라인인 $0.7 \%$ 에 크게 미치지 못한다. 위에서 말했지만 2010년 예비 자료 기준으로 볼 때 한국(0.12\%)은 OECD 국가 중 최하위이며, 평균인 $0.48 \%$ 에도 한참 모자란다. 둘째, 〈표 1〉을 살펴보면 한국의 경우 다자 간 원조에 비해 양자 간 원조의 비중이 높고, 양 자간 원조 중에서도 유상원조 비중이 높다는 것을 알 수 있다.10) 이에 비해 유럽의 여러 국가들은 $100 \%$ 무상원조를 실시하고 있다. 셋째, 한국의 원조는 구속성(tied) 원조11)가 많다. 2008년 기준으로 볼 때 DAC 회원국의 비구속성 비율이 $86.5 \%$ 임에 비해, 한국은 $38.5 \%$ 에 불과하다. 이는 협력국의 개 발 우선순위나 필요에 근거하기보다는 공여국의 제품이나 기술, 자문을 제공하는 데 우선순위를 두고 있기 때문이다. 넷째, 최빈국에 우선적으로 지원해야 한다는 가이드라인과 달리 한국은 최빈국(Least Developed Countries)이나 기타 저소득국(Other Low Income Countries)보다는 하위 중소득국 (Lower Middle Income Countries)의 비중이 상대적으로 높고, 지역적으로도 아시아 및 중동 지역에 편중되어 있는 모습을 보인다. ${ }^{12)} \mathrm{DAC}$ 회원국들의 원조가 아프리카 지역에 집중된 것을 감안하면 세 계적 추세와 큰 차이가 있다(2009년 ODA 10대 협력국은 모두 아프리카 국가들이며 전체 47\%을 차지 하는 반면, 한국은 $20 \%$ 정도이다). 2006년 노무현 대통령이 24년 만에 처음으로 아프리카 3 국(나이지 리아, 알제리, 이집트)을 순방하고, 같은 해 3월 “아프리카 개발을 위한 한국 이니셔티브”를 발표한 이 후 아시아에 대한 편중이 완화되고, 아프리카에 대한 지원이 증가하고 있는 실정이다.

한국의 ODA 예산(양자원조) 배분 과정에 영향을 미친 요인에 관한 경험적 연구13)에 따르면, 1989 년부터 2007 년까지 20 년간 한국과 잠재적 협력국 간의 경제적 이해관계가 예산 배분에 가장 중요한 영향을 미친 것으로 드러났다. ${ }^{14)}$ 즉 협력국에 대한 경제적 영향력 확대가 ODA의 핵심적 동기로 작 용해 온 것이다. 반면, 각 국가들의 인권 관행은 한국 정부의 원조 배분과정에 별다른 효과를 미치지 못했다. 이 연구결과 중 한 가지 흥미로운 사실은 원조관련 중요한 국제회의가 있거나 전 세계적으로

10) 양자간 원조는 원조 자금의 상황여부에 따라 무상원조와 유상원조로 나뉜다. 한국의 경우 무상원조는 외교통상부가 정 책을 총괄하고 주로 KOICA가 사업 수행기관이 되는 반면, 유상원조는 기획재정부가 주관하고 한국수출입은행이 사업 을 수행하는 이원화된 사업 추진체계를 갖고 있다. 한국의 유상원조 비율이 높다는 점은 기획재정부가 지니는 개발협 력에 대한 관점-주로 개도국의 경제성장을 우선시하고 개발협력을 국익 추구의 수단으로 보는과 무관하지 않다.

11) 물품, 용역 및 공사에 대한 조달을 공여국을 포함한 특정국에 제한하는 것을 말한다. 구속성 원조는 혼합신용과 연계 하여 선진공여국의 자본재 수출 증대를 위한 수단으로 많이 활용되었고, 수원국 주도의 투자계획과 자금집행의 최적 화를 저해하여 원조효과성을 낮추는 주요 요인으로 지적되어 왔다. 이에 OECD DAC는 2001년 "최빈국에 대한 비구 속성 원조 권고안"을 채택하여, 구속성 원조 관행을 제한하고 있다. 권율·정지선, 『북유럽 주요국의 언타이드 원조정 책과 시사점』, (서울: 대외정책연구원, 2009), pp. 14-17을 참조.

12) 고경민 · 김순임 - 홍진혁, "공적개발원조(ODA)와 국익: 한국 ODA 정책의 발전을 위한 함의," pp. 108-110.

13) 구정우 · 김대욱, "세계사회와 공적개발원조: 한국 ODA 결정요인 분석, 1989-2007," pp. 181-182.

14) 이것은 물론 비단 한국만의 특징은 아니다. 여러 나라에서 공여국의 수원국에 대한 정치.경제적 영향력 확대가 ODA의 핵심적 동기로 작용해 왔다. 구정우·김대욱, "세계사회와 공적개발원조: 한국 ODA 결정요인 분석, 1989-2007," p. 163 을 참조. 
원조총액이 늘어난 시기에 한국 정부의 $\mathrm{ODA}$ 규모도 증가했다는 점이다. 이에 대해 저자들은 원조 관 련 “규범의 유행”이 원조배분 과정에 영향을 미쳤다고 분석한다. 규범의 유행에 따라 세계적으로 $\mathrm{ODA}$ 금액이 증가하게 되면, 다른 국가들도 이를 규범의 유행으로 인식하고 이에 동조하는 일종의 모 방적 동형화가 일어난다는 것이다.

이러한 분석결과를 통해 $\mathrm{ODA}$ 배분과 관련하여 다음과 같은 두 가지 사실을 유추해 볼 수 있다. 첫 째는 한국 정부는 잠재적 협력국들의 사회적 이해를 반영하기보다는 기업 활동 증진과 자국의 경제 적 이해 증진에 우선적으로 관심을 갖는 점이다. ${ }^{15)}$ 둘째는 국제 사회의 규범을 의식하고, 이를 일정 하게 수용하려는 모습을 보여준다는 사실이다. 이 두 가지 사실은 일견 서로 모순되는 것처럼 보일 수 있지만, 국제협력을 일종의 '선진화된 발전전략'의 일환으로 이해한다는 점에서 근본적인 공통점 을 찾아볼 수 있다.

2010년 10월 국제개발협력위원회가 내놓은 “국제개발협력 선진화 방안”을 살펴보면 이러한 관점 을 잘 엿볼 수 있다. "우리의 개발경험과 국제규범을 바탕으로 원조의 효과성을 높이면서 협력국 중 심의 개발협력 추진”하는 것을 추진전략으로 하고 있지만, 사실상 개발협력이 국가의 위상 제고를 위 한 국가전략의 일환임을 알 수 있다. 그 내용도 한국의 발전모델을 수출16)하고, 한국의 비교우위 분 야와 지역에서 선진국과 공동협력 사업을 강화하는 것이 중심을 이룬다. 유상원조 비율도 2015 년까 지 40\%를 유지하고 있으며, 아시아를 최우선 중점지원 대상으로 하는 기조도 그대로 유지되고 있다. "과거 수원 경험을 거울삼아, 단순한 물질적 시혜가 아니라 진정성을 갖고 꿈과 희망을 주는 새로운 협력방식을 창출”하겠다고 하지만, 협력국이 원하는 원조분야 - 사업을 고려하여 파트너쉽을 하겠다 는 내용만 담겨있다. 여기에서 불평등한 형태의 개발을 촉진하는 정책이나 제도를 주도하거나 지지 하지 않겠다거나, 해외원조의 혜택이 사회의 특정 계층에게 집중되지 않을 수 있는 개발협력 방식에 대한 고려는 찾아볼 수 없다. 이러한 고려가 없는 원조는 자선적 이미지를 전달하는 데 그치고, 협력 국의 공여국에 대한 종속을 낳을 수 있다는 문제점을 지닌다.

한국의 공적개발원조는 양적 측면에서도 문제점을 갖지만, 이를 바라보는 관점 자체가 지나치게 협애하다는 점이 더 큰 문제라고 할 수 있다. 물론 어느 나라도 국제협력을 자국의 이해와 완전히 무 관하게 인도주의적 관점에서만 이해하는 경우는 없을 것이다. 개발을 위한 국제협력은 인도주의에 입각한 측면과 장기적으로 유 · 무형의 국익 증대를 가져오는 국가전략적 측면이 공존한다. 그렇지만 우리의 경우는 암묵적으로 국가전략적 측면만이 강조되고, 국제협력 사업이 담고 있는 가치와 필요 성에 대한 국내적 설득과 공감대 확대는 상대적으로 도외시되고 있다. "국가의 위상"을 제고한다거나 국민적 자긍심을 안겨준다는 점을 홍보한다고 해서 국내적 공감대가 커지는 것은 아니다. 근본적으 로 해외원조 정책은 빈국과 부국사이의 불평들을 줄이기 위한 노력으로, 복지정책을 통해 제공되는

15) 유상원조의 결정에서도 수원국에 대한 수출 증대가 중요한 결정 요인이라는 점이 밝혀진 바 있다. 이재우. "우리나라 공적개발원조의 자원배분 결정요인분석," 『수은해외경제』2005년 10월호 참조.

16) 원조모델로는 새마을 운동, 직업훈련 프로그램, 모자보건 사업이 제시되었다. 
사회적 안전망에 해당되는 국제적 제도이다. 재분배를 통한 '사회적 기회와 안전망 확대'가 인간이 자유를 누릴 수 있는 조건을 제공한다는 공통의 인식이 사회 속에 뿌리내릴 때, 국제협력 사업에 대 한 공감대도 커질 수 있는 것이다. 이와 같이 국내적으로 해외원조에 대한 폭넓은 지지기반이 존재할 때에만 경제위기 등에 흔들리지 않고 국제협력 사업이 정책 일관성을 유지할 수 있다. 다음 절에서는 일본과 스웨덴 사례의 비교를 통해 국제협력을 위한 국내적 토대의 중요성에 대해 살펴보도록 하자.

\section{III. 국제협력을 위한 국내적 토대의 중요성: 일본과 스웨덴 사례}

\section{〈일본의 사례〉}

일반적으로 한국의 ODA 모델은 국익과 경제성에 입각한 일본 모델의 영향을 받은 것으로 알려져 있다. 1977년 이래 일본은 ODA의 양적 확대를 위해 꾸준히 노력해 왔으며, 1989년부터 2000년까지 세계 최대의 원조국이었다. 그러나 아래〈그림 2〉에서 볼 수 있는 것처럼 경제 불황으로 ODA에 대 한 국민여론이 나빠지자 1999년 이후로 지속적으로 감소하고 있다.

\section{〈그림 2〉일본 ODA 예산 추이}

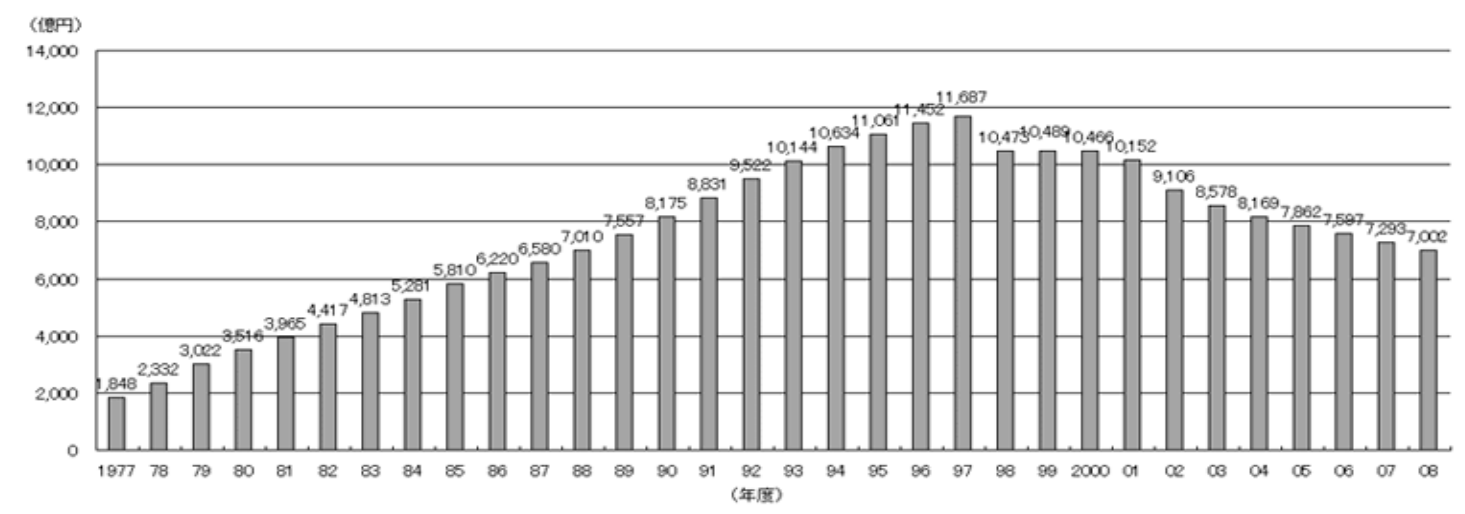

* 출처: 일본외무성 [장준호 - 정복철, “국제개발협력의 두 가지 모델 비교연구," 『세계지역연구논총』제26집 3호, p. 331에서 재인용]

일본의 $\mathrm{ODA}$ 정책은 주로 국제적 차원에서 경제적 헤게모니를 확보하는 수단으로 활용되어 왔다. 일본의 ODA는 일본 기업들이 참여하도록 하는 구속성 원조의 성격을 강하게 띠었고, 일본의 기업 참 여를 보장하는 양허성 차관(유상원조)의 구속성은 일본 ODA 정책의 주요 특징 중 하나였다. 지원 국 가들도 경제블럭 형성을 위해 동남아시아에 집중되었으며, $\mathrm{ODA}$ 를 자국의 경제발전을 위해 장기에 걸친 안정적인 원재료 등의 공급원으로 확보하고자 하는 전략의 일환으로 활용하였다. 이러한 일본 
의 $\mathrm{ODA}$ 정책은 기본 이념과 철학이 명확하지 않았기 때문에 독재정권 지지, 부유층 지원, 인권 억압 에의 악용, 빈곤층 및 원주민 학대, 환경 파괴 등까지도 “개발원조”라는 이름하에 묵인되었다. 17) 그 래서 일본의 $\mathrm{ODA}$ 정책은 세계 최대의 $\mathrm{ODA}$ 공여국이라는 위상에도 불구하고 $\mathrm{ODA}$ 를 자국 기업의 개 도국 시장 진출을 위한 수단으로 활용함으로써 지나치게 경제적 실익을 우선시한다는 비판을 받았 다. ${ }^{18)}$

또한 국내적으로도 해외원조에 대한 부정적인 여론이 증가하면서, $\mathrm{ODA}$ 규모의 축소에 영향을 주 었다. 1997년부터 적극적인 개발지원에 대한 여론이 급격히 줄어들고, 가능한 한 지원을 적게 해야 한다는 국민 여론이 큰 폭으로 증가했다. 경기침체로 인해 국내의 빈부격차가 심해지고 실업률이 높 아짐에 따라, 해외개발원조에 대한 불만의 목소리가 커진 것이다. 여기에 2001년 불거진 ODA 관련 비리사건으로 국민들의 부정적 인식이 증폭되면서, $\mathrm{ODA}$ 정책과 관련해 국민의 이해 및 지지를 증진 하는 일이 중요한 과제로 부각되었다. ${ }^{19)}$

이에 따라 일본 정부는 2003년 8월 "ODA 대강"을 수정하여 ODA의 목적을 “국제사회의 평화와 발 전에 공헌하며 일본의 안전과 번영의 확보에 기여"하는 것으로 설정하고, ODA에 정책의 투명성을 높 여 국민의 신뢰를 확보하기 위한 평가와 개선 작업을 진행해 왔다. ${ }^{20)}$ 이 대강에서는 “열린 국익”이라 는 개념을 제시하여, 끊임없이 제로섬적인 배타적 국익의 추구가 아니라 국제경제체제와 국제 질서 의 유지· 강화, 개도국의 발전 및 민주화라고 하는 국제적 공공선에 기여하는 것을 강조하였다. ${ }^{21)}$

일본의 사례는 해외원조 정책이 국익을 위한 단기적 투자로 비춰질수록, 국내에서 국가복지의 혜 택을 받지 못하는 빈곤층에 대한 사회정책이 미비할수록, 국제개발협력에 대한 국내적 정당성이 취 약할 수밖에 없음을 보여준다. 이 경우, 국내적 경제상황이나 여론의 향방에 따라 국제협력 사업의 정책일관성이 크게 흔들릴 수밖에 없다. 해외원조 정책을 추진하는 정부는 국내정치적 여론에 대한 응답성과 국제적 책임성이라는 두 가지 압력을 받는다. 이 두 가지를 조율하면서 일관된 해외원조 정 책을 추진하기 위해서는 광범위한 정당성을 제공해 줄 있는 보편적 가치와 원칙을 확립해 나갈 필요 가 있는 것이다.

\section{〈스웨덴의 사례〉}

스웨덴의 경우, 원조에 대한 폭넓은 지지기반을 바탕으로 높은 ODA/GNI 비율을 원조 정책 초기 부터 지속적으로 유지해 온 대표적인 국가이다. 스웨덴은 2 차대전 이후 아시아, 아프리카 지역에 대

17) 장준호 - 정복철. “국제개발협력의 두 가지 모델 비교연구: 독일과 일본의 공적개발원조(ODA)를 중심으로," 『세계지역 연구논총』제26집 3호, pp. 329-330.

18) 고경민 · 김순임 · 홍진혁, "공적개발원조(ODA)와 국익: 한국 ODA 정책의 발전을 위한 함의," p. 103.

19) 장준호 · 정복철. "국제개발협력의 두 가지 모델 비교연구: 독일과 일본의 공적개발원조(ODA)를 중심으로," pp. 332-333.

20) 이에 대한 보다 자세한 설명은 장준호·정복철. "국제개발협력의 두 가지 모델 비교연구: 독일과 일본의 공적개발원조 (ODA)를 중심으로," p. 334를 참조.

21) 고경민·김순임·홍진혁, "공적개발원조(ODA)와 국익: 한국 ODA 정책의 발전을 위한 함의," pp. 105-106.. 
한 지원을 시작으로 1960 년대부터 본격적으로 원조를 공여하기 시작했다. 빈곤국에 대한 국제적 연 대주의, 협력국의 우선순위에 대한 존중, 빈곤 퇴치에 대한 뚜렷한 목표의식 등 스웨덴 원조의 특징 은 지난 수십 년간에 걸쳐 큰 변화 없이 꾸준히 유지되어 왔다. 스웨덴은 다른 DAC 회원국에 비해 다자간 원조의 비율이 높으며, 아프리카 및 최빈국에 대한 지원비중이 크고, 부분별로는 인도적 지원 과 사회 인프라에 대한 지원 집중 경향이 강하다. 또한 공공재정시스템을 적극적으로 활용하도록 노 력하고, 재정지원과 같은 새로운 원조방법을 앞장서서 활용하며 수원국의 제도개발, 역량 강화에 역 점을 두고 있다. 스웨덴은 무역, 이주, 환경, 여성 등 개발원조와 관련된 모든 분야에서 가장 정책일 관성이 높은 대표적인 나라이다. ${ }^{22)}$ 이는 스웨덴뿐만 아니라 노르웨이, 덴마크 등 북유럽 국가들에서 공통적으로 나타나는데, 이들 북유럽 국가들은 국제사회에서 독자적이고 모범적인 원조정책으로 주 목을 받아 왔다. 빈곤퇴치를 위한 국제적 연대주의라는 일관되고 명확한 정책 목표 하에 ODA의 양적 확대는 물론 질적 수준을 제고하면서 원조형태 및 지원조건에서 국제사회의 주도적 역할을 담당하고 있다. 전반적으로 상업적 이익, 안보, 지정학적 관계보다는 사회민주주의 가치를 확산하기 위해 원조 를 사용했다는 평가를 받고 있다. 최근에는 '북유럽 원조모델'의 차별성이 다소 약화되고 있기는 하 지만, 여전히 국제사회의 원조체제 개선과 $\mathrm{ODA}$ 효과성 제고에 적극적인 노력을 기울이고 있다. 개발 을 위한 정책일관성(PCD: Policy Coherence for Development) 면에서도 다른 DAC 국가에 비해 앞 선 노력을 추진해옴으로써 원조정책 문서에 정책일관성의 중요성을 뚜렷이 명시하고 있다. ${ }^{23)}$

스웨덴의 국제개발협력 정책의 일관성은 '연대성'의 가치가 정치적 실천과 담론의 중심에서 작용해 왔기 때문에 가능했다. 스웨덴 연대성의 기본 정신은 "타자의 입장에서 보는 것”이다. 이러한 "타자" 는 자국 국민에 국한되지 않는다. 스웨덴 사회에서 연대성이라는 말은 국가 주권을 뛰어넘는 보편적 가치를 지닌다. 이에 대해 스웨덴의 전 외무부 장관인 엘리아손(Eliasson)은 최근에 다음과 같이 말 한 바 있다. "스웨덴의 외교정책에서 연대성은 스웨덴 국민들이 지닌 정의에 대한 강한 관념 즉, 모 든 사람-국내적으로나 국제적으로-의 평등한 가치, 모든 사람의 존엄한 삶이라는 가치에 기초한 다.” 연대성에 대한 이러한 사고가 국경을 뛰어넘은 도덕적 의무에 대한 합의를 형성해 온 것이다. ${ }^{24)}$

무엇보다 스웨덴의 복지국가 제도가 연대성의 실질적 의미를 구현하고, 사회적 연대성의 가치를 배양해 온 토대가 되었다. 스웨덴의 복지국가 모델은 모든 사람을 평등하게 대우하고, 시민들 사이의 사회경제적 장벽을 철폐하고자 했던 보편주의 원칙을 담고 있다. 이것은 사민당 초기 사회 민주주의 적 비전을 담고 있는 “가정의 국민"(folkhemmet)25)이라는 개념에서도 엿볼 수 있다. 스웨덴의 복지

22) 권율 - 정지선, 『북유럽 주요국의 언타이드 원조정책과 시사점』, (서울: 대외정책연구원, 2009), pp. 37-38.

23) 권율 · 정지선, 『북유럽 주요국의 언타이드 원조정책과 시사점』, pp. 20-22.

24) Bergman, Annika, "Co-Constitution of Domestic and International Welfare Obligations," pp. 80-81.

25) "국민의 가정"이라는 개념은 1928년 당의장직을 맡게 된 페르 알빈 한손(Per Albin Hasson)이 만든 개념이다. 이것은 원래 보수적인 기원을 지닌 개념인데, 이후 사민당과 뗄 수 없는 관계가 되었다. 그는 다음과 같이 이 개념을 설명한다. "가정이란 근본적으로 공동체, 그리고 함께함을 뜻한다. 또한 아이들을 편애하거나 홀대하지도 않는다. 이를 국민과 시민의 위대한 가정이라는 개념에 적용할 경우, 이는 오늘날의 시민들을 특권을 가진 자와 천대받는 자로, 지배자와 종속자로, 부자와 빈자로, 자산 소유자와 빈털터리로, 약탈자와 약탈당한 자로 갈라놓는 모든 사회적 - 경제적 장벽의 철폐를 의미할 것이다." 버먼, 셰리, 『정치가 우선한다』, p. 242-243 참조. 
국가 모델은 모든 시민이 일반적 복지를 향유할 수 있도록 보장했으며, 이를 통해 협소한 자기이익보 다는 이타심에 기초한 평등주의적 정치문화를 형성해 왔다. 이는 다시 스웨덴의 국제적 연대주의의 토대가 되었으며, 국내적 사회 민주주의와 국제적 연대주의가 상호 구성적으로 작용하는 계기가 되 었다. ${ }^{26)}$

복지국가와 해외원조의 친화성에 대해서는 다양한 측면-국내적 사회지출 수준, 정부의 당파성 (partisanship), 복지국가 속성들-에서 경험적으로 연구되었다. 공여국의 국제개발협력 정책은 국 내적 사회지출과 양의 상관관계를 지닌다. 강한 복지 프로그램을 지닌 국가들은 강한 국제개발협력(원 조) 프로그램을 지니는데, 국제개발협력과 복지국가 정책이 동일한 가치를 표현하기 때문이다. 또한 복 지국가를 통해 제도화된 가치와 원칙은 국제개발협력 정책을 결정하는 중요한 요인으로 작용해 왔다. ${ }^{27)}$

한국 사회가 당장 스웨덴과 같은 국제개발협력 정책을 펼쳐야 한다고 주장하는 것은 아니다. 중요 한 사실은 국가 내에 제도화된 가치와 원칙이 국제개발협력 정책에 반영된다는 점이다. 따라서 국내 적으로 소득재분배 정책이 갖는 가치와 실천이 광범위하게 확립되는 것이 무엇보다 중요하다. 복지 가 시민으로서 향유해야 할 보편적 권리로 인정되고 이를 위한 시민의 의무가 받아들여질 때에만, 국 제개발협력에 대한 지속적인 동의와 지지를 얻을 수 있기 때문이다. 그렇지 않을 경우, 국제개발협력 정책은 경제 상황이나 국내 여론에 따라 언제든 축소 - 변경될 수 있을 것이다. 다음 절에서는 국내적 복지정책의 확대와 접목될 수 있는 공적개발원조의 방향에 대해 살펴보도록 하자.

\section{IV. 공적개발원조의 방향: 인권으로서의 개발}

UN은 2000년 9월 세계 189개국 정상들이 참석한 밀레니엄정상회의(Millennium Summit)에서 인 류의 평화, 인간안보, 개발, 인권, 기본적 자유를 위해 국제 사회가 공동 노력을 기울이자는 "밀레니엄 선언문”을 채택했다. 그리고 각국 정상들은 2015년까지 달성해야 할 “새천년개발목표”(Millenium Development Goals)를 설정했다. 밀레니엄정상회의 5주년인 2005년 제60차 UN총회에서 코피 아난 사무총장은 정의롭고 평화로운 세계를 만들기 위한 필수 요소로 "빈곤으로부터의 자유, 공포로부터의 자유, 존엄한 삶을 위한 자유” 등의 세 가지 자유와 각각의 자유에 상응하는 발전, 인간안보, 인권의 상호연관성을 제시했다. ${ }^{28)}$

이에 따라 ODA의 목표도 선 · 후진국 간의 개발격차를 완화하기 위한 경제적 지원 사업에 국한되 지 않고, 개도국 국민의 인간안보나 인권과 같은 보다 근본적인 문제로 확장되었다. 또한 2005년 파

26) Bergman, Annika, "Co-Constitution of Domestic and International Welfare Obligations," pp. 83-84.

27) 이와 관련한 보다 상세한 설명은 Noël, Alain and Jean-Philippe Thérien, "From domestic to international justice: the welfare state and foreign aid," pp. 523-53; Zimmerman, Robert A, "The determinants of foreign aid," Les Cahiers du CEDIMES 2, No. 2 (2008), pp. 109-137을 참조.

28) 고경민 · 김순임 · 홍진혁, "공적개발원조(ODA)와 국익: 한국 ODA 정책의 발전을 위한 함의," p. 101. 
리선언(Paris Declaration on Aid Effectiveness)을 통해 ODA가 원조 공여국의 국익 추구를 위한 외 교적 · 경제적 수단이라는 협소하고 배타적인 의미에서 벗어나 협력국의 필요를 적극적으로 고려하 는 방향으로 이루어져야 한다는 데 합의가 이루어졌다. ${ }^{29)}$ 개발원조는 현지 행위자들이 자발적으로 참여하는 내재적인 과정이 되어야 하며, 공여자는 현지의 사회정치적 시스템과 행위자가 실질적인 개발의 주체가 될 수 있도록 환경을 조성할 책임이 있다는 것이다.

최근의 개발 개념은 물질적 성취나 경제성장뿐만 아니라 사회 · 문화 - 정치적 변화를 포함한 포괄 적 과정으로 이해된다. 개발의 궁극적 목적은 웰빙30)의 점진적이고 공정하며 지속적인 증진이다. 이 런 관점은 국민총생산, 산업화, 수출 성장, 자본 유입의 단순 증가에 초점을 두었던 기존의 전통적인 경제성장 관념과 대조적이다. ${ }^{31)}$ 결코 도래하지 않을 성장의 꼭짓점을 향해 매진할수록 가진 자와 못 가진 자 간의 권력 자원의 불균형은 점점 돌이킬 수 없게 되고, 당연히 분배는 갈수록 요원해진다. 성장 그 자체는 이미 권력적 현상이기 때문에, 거기에 대응하는 권력적 장치로서 제도적 분배 장치가 동시에 마련되지 않으면 성장은 오히려 분배의 악화를 가져오기 쉽다. 이런 점에서 단순한 경제성장 은 인류의 자유를 오히려 축소시킬 수 있다. 그래서 최근의 '개발권'(Right to Development)과 '인권 에 기초한 개발 개념은 물질적 증진을 향한 열망과 자유와 존엄을 향한 열망이 서로 조화롭게 발전 할 수 있도록 하는 데 초점을 맞추고 있다. 인권의 틀 안에서 사람들이 스스로 선택하고 자유를 행사 할 수 있도록 세력화(Empowerment)하는 과정을 개발 과정에서 현실화하는 것이다. 이를 위해서는 인권 기준과 원칙을 지침으로 개발 정책이 수립되고, 프로그램이 운영되어야 하며, 인권을 실행 가능 한 것으로 만들어야 하고, 동시에 그 과정에서 나온 혜택이 가장 가난하고 취약한 사람들에게 돌아갈 수 있도록 관련된 정치적 · 법적·행정적 제도를 보장해야 한다. ${ }^{32)}$

우리가 추진해야 하는 공적개발원조의 방향은 정부가 내놓은 “국제개발협력 선진화 방안”에서 제 시된 것처럼 단순히 과거 한국의 발전모델을 전파하는 데 있지 않다. 세계 최초로 수원국에서 공여국 으로 전환한 국가로서 우리가 할 수 있는 역할은 과거에 경험한 해외원조의 부정적 측면들이 다른 수 원국에서 재발되는 것을 막는 것이다. 또한 한국의 발전모델이 갖는 한계를 반성적으로 검토하고, 경 제성장이 독재와 불평등의 심화로 이어지지 않을 수 있는 개발방식을 협력국과 함께 고민해야 한다. 개도국에 필요한 것은 성장 자체가 아니라 성장의 과실을 포함한 한 사회가 동원할 수 있는 가용 자 원이 안정적이고 투명하게 분배되는 제도화가 동반된 성장이다. 국제개발협력을 통한 성장이 혜택의 공정한 분배를 보장할 수 있는 제도와 관행으로 정착되지 않는다면, 성장의 혜택이 특정 엘리트의 권 력 자원으로 변질되고 말 것이기 때문이다.

29) 고경민 · 김순임 · 홍진혁, "공적개발원조(ODA)와 국익: 한국 ODA 정책의 발전을 위한 함의," pp. 101-2.

30) 이때 '웰빙'은 한국에서 이해되는 것처럼 개인적으로 행유되는 고급문화가 아니라 사회적으로 구성되는 개인의 삶의 질을 뜻한다.

31) 안드레아슨, 보르 · 스티븐 마크스 편저, 양영미 - 김신 역, 『인권을 생각하는 개발지침서』, (서울: 후마니타스, 2010), p. 21.

32) 안드레아슨, 보르 · 스티븐 마크스 편, 『인권을 생각하는 개발지침서』, pp. 15-6. 
새로운 개발 개념을 통해 한국의 발전모델을 비판적으로 검토하는 것은 우리의 현재를 돌아보는 데에도 도움이 된다. 한국 사회에서 개발은 사실상 일인당 실질소득의 증가와 동일시되어왔다. 그러 나 최근에는 실질소득의 증가가 개인의 '삶의 질'을 증진시키기 위한 최소한의 요건조차 모두 충족시 키지 못한다는 점이 확인되고 있다. 경제학자 아마티야 센은 역량 접근법(Capability Approach)을 통해 빈곤이 단순히 소득이 낮다는 것을 의미하기보다는 "기본적인 역량의 박탈"을 의미하며, "개인 이 소유한 역량이란 자신이 가치 있다고 여기는 삶을 영위하기 위해 누리는 실질적인 자유”라고 주장 했다. 기본적인 역량이란 “결정적으로 중요한 어떤 요소들을 최소한의 수준까지 만족시킬 수 있는 능 력”이며, 모든 사람들은 역량을 소유할 자격을 획득할 수 있게 해주고 또 이를 촉진시키는 정치 - 경 제 - 사회제도에 대한 접근성이 부여되어야 한다는 것이다. ${ }^{33)}$ 이러한 관점은 한국 사회가 개인이 자 신의 삶을 진정으로 선택할 수 있는 충분한 사회경제적 조건을 제공하고 있는지에 대한 질문을 던져 준다. 만약 그렇지 않다면, 한국 사회의 경우에도 여전히 빈곤 문제를 고민해야 하고, 이를 해소하기 위한 노력이 필요하다는 점을 말해준다.

\section{V. 결 론}

이 글에서 구체적으로 어떻게 ODA 정책을 실행해야 하는지에 대해서는 애기하지 않았다. 근본적 인 문제점은 국제협력사업을 바라보는 국내적 관점이 지나치게 협애하다는 점이다. 이러한 관점의 협애성이 양적 빈약성의 원인이 된다. 그러므로 실현가능한 구체적인 국제개발협력 모델을 수립하기 에 앞서, 어떤 방향에서 정책을 고민하고 집행해야 하는지 관점을 수립하는 것이 우선되어야 한다. 이 과정에서 국내의 복지 정책과 해외개발협력 사업에 공통적으로 적용될 수 있는 제도화된 가치와 원칙을 수립하는 게 중요하다. 개인이 자유롭게 자신의 삶을 선택할 수 있는 역량을 보장하는 사회경 제적 조건이 필요하다는 점이 폭넓게 인정되고 복지정책을 통해 실천된다면, 멀리 떨어진 다른 나라 사람들에게 도움을 주어야 할 도덕적 의무도 보다 큰 공감대를 얻을 수 있기 때문이다.

국제개발협력을 통한 개발 과정에서 (1) 모든 개인의 능동적이며 자유롭고 의미 있는 참여를 촉진 해야 한다는 점, (2) 기술 관료적 정책결정을 피하고 현지의 지식과 수요를 개발 과정에 통합한 프로 그램이 실행될 수 있도록 해야 한다는 점, (3) 개발 혜택이 공정한 분배를 가져올 수 있는 제도화에 힘써야 한다는 점, (4) 국제개발협력이 경제적 국익 추구의 도구가 되거나 협력국의 종속을 초래해서 는 안 된다는 점 등을 기본 원칙으로 할 수 있을 것이다. ${ }^{34)}$ 이러한 원칙 하에서 ODA의 양을 늘리고, 최빈국을 우선적으로 지원하며, 무상원조와 비구속성 원조를 점진적으로 확대하는 한국적 정책 방향 을 수립해 나가야 한다. 이 과정에서 협력국 현지시스템을 활용해 투명성을 높이고, 부패예방조치를

33) 이금순 · 김수암 · 조한범 · Lynn Lee, 『국제 개발이론 현황』, (서울: 통일연구원, 2008). pp. 56-57.

34) 안드레아슨, 보르 · 스티븐 마크스 편, 『인권을 생각하는 개발지침서』, pp. 21-23. 
마련한 북유럽 국가들의 구체적인 정책들을 도입할 수도 있을 것이다.

약간 맥락은 다르지만, 케인스는 『평화의 경제적 귀결』(The Economic Consequences of the Peace)이라는 책에서 1 차 대전 후 독일의 전쟁 배상 문제를 논의한 파리회담에 대해 다음과 같이 적고 있다.

“유럽의 미래는 그들의 관심사가 아니었고, 유럽의 생존 수단은 그들의 걱정 밖이었다. 옳든 그 르든 그들이 집착한 것은 국경과 국민감정, 세력균형, 제국적 팽창, 강하고 위험한 적국 하나를 영 원히 불구로 만드는 일, 복수, 승전국들의 어마어마한 재정적 짐을 패전국에게 이전하는 것과 관 련되어 있었다.”35)

케인스는 모름지기 “값진 평화”라면 유럽이 직면한 생활수준의 “절대적 저하”라는 문제에 직접 적으로 답해야 한다고 생각했다. 그럼에도 불구하고 조약체결자들은 이 문제를 외면했고, 그 결과 (반드시 그들의 책임은 아니지만) 유럽은 더 궁핍해졌다. 이러한 결과에 이른 요인의 하나는 바로 정치인들의 사상적 빈곤이었다.

35) 스키델스키, 로버트 저, 고세훈 역, 『존 메이너드 케인스 1』, (서울: 후마니타스, 2009), p. 431. 


\section{참고문헌}

\section{1. 국내문헌}

고경민 · 김순임 · 홍진혁, “공적개발원조(ODA)와 국익: 한국 $\mathrm{ODA}$ 정책의 발전을 위한 함의", 『한국과 국제정치』제26권 3호 (2010), pp. 95-128.

고세훈, 『복지한국, 미래는 있는가』, (서울: 후마니타스, 2009[개정판]).

구정우·김대욱, "세계사회와 공적개발원조: 한국 ODA 결정요인 분석, 1989-2007,"

『한국사회학』 제45집 1호 (2011), pp. 153-190.

국제개발협력위원회, “국제개발협력 선진화 방안," 2010년 10월 25일.

권율·정지선, 『북유럽 주요국의 언타이드 원조정책과 시사점』, (서울: 대외정책연구원, 2009). 버먼, 셰리 저, 김유진 역, 『정치가 우선한다』, (서울: 후마니타스, 2010), p. 291. 스키델스키, 로버트 저, 고세훈 역, 『존 메이너드 케인스 $1 \unlhd$, (서울: 후마니타스, 2009). 안드레아슨, 보르·스티븐 마크스 편저, 양영미· 김신 역, 『인권을 생각하는 개발지침서』, (서울: 후마니타스, 2010).

이금순 · 김수암·조한범· Lynn Lee, 『국제 개발이론 현황』, (서울: 통일연구원, 2008). 이재우, “우리나라 공적개발원조의 자원배분 결정요인분석." 『수은해외경제』. 2005년 10 월호. 장준호 - 정복철. "국제개발협력의 두 가지 모델 비교연구: 독일과 일본의 공적개발원조(ODA)를 중심으로,"『세계지역연구논총』제26집 3호, pp. 311-338.

\section{2. 국외문헌}

Bergman, Annika, "Co-Constitution of Domestic and International Welfare Obligations," Cooperation and Conflict 42, No. 1(2007), pp. 73-99.

Esping-Andersen, Gøsta, The Three Worlds of Welfare Capitalism, (Princeton: Princeton U. P., 1990). Noël and Jean-Philippe Thérien. "From Domestic to International Justice: The Welfare State and Foreign Aid," International Organization 49, No. 3 (1995), pp. 523-53.

Zimmerman, Robert A, "The determinants of foreign aid," Les Cabiers du CEDIMES 2, No. 2 (2008), pp. $109-137$. 